\title{
頭頸部悪性腫瘍に対する免疫療法の検討
}

浅一岡一 一

\section{A Study on Immunotherapy of Malignant Tumors of the Head and Neck}

\author{
Kazuyuki Asaoka
}

(Keio Univ.)

Fifty-five patients with cancer of the head and neck were treated in the Oto-rhinolaryngology Department of Keio University in the period between Oct., 1974 and Dec., 1977. These patients were divided into the immunotherapy group, where immune activators (OK-432, PS-K, SSM) were long administered after radical treatment of cancer, and the control group, and immunotherapy was analyzed in the light of clinical progresses and immunologic parameters. Findings that served as immunologic parameters were $\mathrm{CH}_{50}$, PPD response and peripheral blood lymphocyte count. Administration of immunologic activators was aimed at reduction in size of tumor or arrest of its growth in the non-radical therapy group, and prevention of recurrence and metastasis in the radical therapy group.

The results were as follows:

1. OK-432, PS-K or SSM had no tumor-reducing effect in the non-radical therapy group (cancer-bearing patients).

2. Immunologic findings suggest that OK-432, PS-K and SSM have prophylactic effects against recurrence and metastasis.

3. The immunologic response of cancer in vivo is not always advantageous to the body. Administration of immune activators may not, therefore, be indicated in some cases. Further studies are necessary in this respect.

4. To enhance the effect for tumor shrinkage and prevention of recurrence or metastasis, immunochemotherapy requires further study.

\section{I .は じめに}

癌の治療は従来, 手術, 放射線, 化学療法が中心をなしていたが, 最近第 4 の治療法としての免 疫療法が注目されている.

癌の免疫療法の歴史は古く，すでに今世紀の初めに感染症に対する免疫と同じような考えから， 癌のワクチン療法，血清療法がおとなわれたが，充分な治療効果をあげるととができず，その後は あまり顧みられなかった。しかし, 近年における免疫生物学, 免疫化学, 免疫遺伝学, 免疫病理学な 
どの発展とともに, 腫瘍免疫に関する研究も盛んにおこなわれるようになり, 癌の免疫療法が再び 脚光をあびるようになった，即ち，1969 年に Mathé ${ }^{1)}$ が急性白血病患者に，1970年に Morton ${ }^{21}$ が悪性黒色腫患者に B C G 生菌を用いた兔疫療法により，寛解期間の延長または延命効果を認めた と報告して以来，急速に B C G をはじめとする免疫賦活剂を用いる免疫療法が䧄床に導入されはじ めた。

癌の免疫療法は3 4), 能動的免疫療法, 受動的免疫療法, 非特異的免疫療法に分けられているが, 特異的免疫療法は現状では問題点む多く臨床には使用不可能である. 現在臨床において行なわれて いる免疫療法は，主として免疫賦活剂による非特異的免疫療法である.

現在臨床で多く使用されている免疫賦活剂は，B C G， O K-432などの細菌または菌体成分を用 いるもの，PS-K，レンチナンなどの植物多糖体，レバミン゙ールなどの化学物質などである，しか しながら現時点での免疫賦活剤単独使用では，確実な抗腫癔効果を得るととはまず不可能であると いってあ過言ではない.

一方, 癌の手術療法, 放射線療法, 化学療法の進歩屯著しいが，乙れらの治療にて最大の効果を 得たとしても，癌細胞のすべてを排除することは困難なととが多く，再発転移の危険性が生じてく る. この残疜する少量の癌細胞を消滅させる決め乎となるのが担癌者の免疫能であり， そとに免疫 療法の意義もあると思われる。

人癌の病理組織の所見では，間質の細胞浸潤が多いほど，特にリンパ球の浸潤が強いほど予後が よいといわれている. 免疫学的にはリンパ球, 特に T-cell やマクロファージは癌特異抗原の認識 や抗腫瘍作用を起す反応の主役とみなされている．また，T-cell やマクロファージの機能を反映 するとされているパラメーターと担癌者の病期や予後とが一致するとされている．とのように担癌 者の免疫能を知る指標として, 細胞性免疫能の検討が主に行なわれている. しかし, 癌の免疫機構 には体液性免疫も関与しており, 細胞性免疫之協調的に生体の防御機構を形成していると考えられ ている(5)7)8).

担癌者の免疫能を知る最良のパラメーターは, 癌の特異的免疫応答による方法であるが，現状で は実用困難で，一般的な免疫応答力をみる方法が多く用いられている．乙の癌に対しての非特異的 な免疫応答により癌患者の免疫能を検討するととは, 必ずしも予後と一致を見ない場合ああり, 複 数のパラメーターの测定により, 総合的な判定が必要と思われる ${ }^{91}$.

慶大耳鼻科では, 昭和 49 年 7 月より頭頸部悪性腫瘍患者の免疫能を知るため, 患者にとって負担 が少なく，比較的容易に定量できるパラメーターとして，体液性免疫の面より血清総補体価 $\left(\mathrm{CH}_{50}\right.$ と略), 細胞性免疫の面よりッベルクリン皮膚反応（ツ反応または P P D反応と略）および D N C B皮膚反応, 補助検査として末梢血リンパ球数を測定している.

中島 ${ }^{10)}$ は，頭頸部悪性腫瘍 197 例を治療前，治療中，治療後，寛解， 5 年治癒，再発転移，末期 の 7 群に分類し, 上記の免疫学的パラメーターを用いて検討した結果, 西岡ら ${ }^{5)}$ の提唱している 「ツ反応と補体による 6 期分類」を用いるととにより，予後良好例は 6 期分類上を時計回りに動き 予後不良例は反時計回りに動くことを報告した.

本研究に执いては，根治治療法を受けた頭頸部癌患者に対し，再発転移防止を目的として免疫賦 活剂を単独で投与した。しかし結果的に 3 力月以内に再発を来した症例については腫瘍の増殖停止 や縮小を目的として投与した。一方免疫療法を検討するに当り, 患者の臨床経過を観察すると共に 免疫学的パラメーターとして $\mathrm{CH}_{50}$, ッ反応, 末梢リンパ血球数を経時的に測定した。 な拉, 使用 した免疫賦活剂は，OK-432，PS-K，丸山ワクチン（S S M と略）である. 
II. 対

対象は慶大耳鼻科において, 昭和 49 年10月よ り昭和 52 年 12 月までの期間に, 根治手術, 根治 照射などの癌根治治療法を行ない, 経時的に臨 床経過と前述の免疫学的パラメーターを観察し 得た頭頸部癌患者55症例である.

対象例の腫演発生部位は, 表 1 亿示すごと $く$, 鼻副鼻腔, 口腔, 咽頭, 喉頭が主となって いる.

年令分布は，最年少13才，最高令者77才，平 均54才であり，性比は男性38例，女性17例であ る(表 2 ).

対象の55症例のうち免疫賦活剤の投与を行な った症例は41例で, 残り14例は対照群である. 対照群は根治治療法のみを行ない，昭和52年 12
象

月末まで, 最低 1 年以上再発転移を認めない症 例群である。

免疫療法を検討するに当り，根治治療後に免 疫賦活剂を投与した41症例を「根治群」と「非 根治群」に分けた。即ち，結果上り見て根治治 療法後 3 力月間は臨床的に再発転移を認女ない 症例を「根治群」（23例）とし，根治治療法後 3 力月以内に再発を認めた症例を「非根治群.」 （18例）とした。なお，各種免疫療法群におけ る例数之平均年令は表 3 に示すどとくである. 免疫賦活剂の投与期間は，「非根治群」では 3 力月以上の投与, 「根治群」では最低 4 力月 投与にて中止した症例むあるが，原則として 6 カ月以上の投与を行なっている.

表 I 腫瘍発生部位

\begin{tabular}{|c|c|c|c|c|c|}
\hline 腫瘍発生部位 & 対 照 & $\mathrm{O} K-432$ & $P S-K$ & S SM & 計 \\
\hline 鼻副鼻腔 & $6(1)$ & $7(2)$ & $6(2)$ & $2(1)$ & $21(6)$ \\
\hline 口腔 & 2 & 5 & $3(2)$ & $3(1)$ & $13(3)$ \\
\hline 上 咽 頭 & 2 & $6(3)$ & 3 & 1 & $12(3)$ \\
\hline 中咽頭 & 1 (1) & & & & 1 (1) \\
\hline 下咽 頭 & 1 & & & 1 (1) & 2 (1) \\
\hline 喉 頭 & 2 (1) & 1 & 1 & & 4 (1) \\
\hline 耳下腺 & & 1 (1) & & 1 (1) & $2(2)$ \\
\hline 計 & $14(3)$ & $20(6)$ & $13(4)$ & $8(4)$ & $55(17)$ \\
\hline
\end{tabular}

症例数の左側は総数，（）内は女性数を示す.

表 2 年令分布及び性別

\begin{tabular}{|c|c|c|c|c|c|}
\hline 年 令 & 対 照 & $\mathrm{OK}-432$ & $\mathrm{P} S-\mathrm{K}$ & S SM & 計 \\
\hline $10 \sim 19$ & 1 & 1 & & 1 & 3 \\
\hline $20 \sim 29$ & $2(1)$ & 1 & 1 & & $4(1)$ \\
\hline $30 \sim 39$ & & 1 (1) & $1(1)$ & & $2(2)$ \\
\hline $40 \sim 49$ & 1 & $3(2)$ & & 1 & $5 \quad(2)$ \\
\hline $50 \sim 59$ & $6(1)$ & $5(2)$ & $5(3)$ & $2 \quad(2)$ & $18(8)$ \\
\hline $60 \sim 69$ & $3(1)$ & 4 & 5 & $4(2)$ & $16(3)$ \\
\hline 70以上 & 1 & $5(1)$ & 1 & & 7 (1) \\
\hline 計 & $14(3)$ & $20(6)$ & $13(4)$ & $8(4)$ & 55 (17) \\
\hline
\end{tabular}

症例数の左側は総数，（）内は女性数を示す. 


\section{III. 免 疫 賦活 剤}

1. OK-432 (Picibanil)

癌患者が丹毒に罹患すると，癌の退縮が見ら れたという報告 ${ }^{11)}$ 亿もとづき，岡本ら ${ }^{12)} は ， A$ 群 streptococcus hemolyticus の $\mathrm{Su}$ 株のぺ ニシリン処理凍結乾燥菌体を開発した。 $1 \mathrm{KE}$ は菌体 $0.1 \mathrm{mg}$ に相当する。 in vivo では，腫瘍 に対する直接作用とともに，宿主の免疫能を介 しての間接的抗腫暘作用を有している ${ }^{13)}$.

投与方法は, 臨床では動静脈内, 腫瘍局所内, 皮下，皮内，筋肉内，獎膜腔内などに投与され ている。

本研究では, 主として根治治療法の再発転移 の予防を主目的としているため, 外来通院にお ける長期間の投与が必要であり，比較的副作用 の少ない筋注法を行なった。使用量は， $0.2 \mathrm{~K}$ Eまたは0.5K Eより開始して，漸増してゆき， 維持量として, 週 1 回, $3 \sim 5 \mathrm{KE}$ の筋注を行 なった。

\section{PS-K (Krestin)}

PS- $\mathrm{K}^{14) 15)}$ は，1965年滋賀県で胃癌末期之診

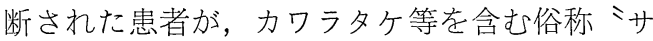
ルノコシカケミの熱水抽出物を服用して日常生 活に復帰した事実により研究開発された. PS-K は，担子菌類 basicliomycetes のサルノコ シカケ科に属するカワラタケ Corilus vesicolor Quē1 の一系統である CM-101 株を培養し て得られた菌系体より抽出された蛋白多糖体で ある。

通常，経口投与がおてなわれ，腫瘍に対して は，直接抗腫瘍作用屯認められるが，宿主介在 性の抗腫瘍作用が主体とされている。経口投与 による副作用，毒性屯低い。

本研究では， 1 日 $3 \mathrm{~g}$ を分 3 で経口投与を行 なっている。

3. 丸山ワクチン（結核菌体抽出物質; S S M之略)

丸山神は，結核菌体抽出物質が，結核や癭に
有効であり，また結核患者や㾋患者に癌の発生 が稀であるという事実により，S S Mを癌患者 にも使用した。

S SMは，ヒト型結核菌 $\mathrm{H}_{37} \mathrm{Rv}$ を Sauton 培地培羪, 酸性下に熱水抽出し, 除蛋白, 透 析後にアルコール不溶性，水可溶性分質を分離 抽出したもので，その $1 \%$ 溶液を原液として， さらに $1.0 \gamma / \mathrm{ml}, 0.1 \gamma / \mathrm{ml}$ の生理食塩水稀橎液

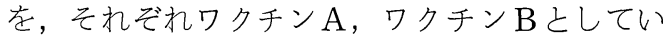
る. 成分は主として, 多糖類, 核酸である ${ }^{17)}$.

投与方法は，皮下注が行なわれ，副作用，毒 性は認めない。

本研究に打ける投与方法は，隔日にワクチン A，ワクチンBを交互に皮下注射を行なった。

\section{4. 免疫賦活剂の適応と選択}

本研究における免疫賦活剂の適応は，原則と して無作為に行ったが，根治治療法として放射 線単独の症例，放射線と化学療法の併用の症例 根治手術を行なっているが比較的再発の可能性 の高い症例などを対象とせざるをえなかった。 また，S SMのように，患者や家族の希望によ り投与した症例むある。，一方，それら以外の根 治性の高い，再発の可能性の少ない症例が対照 群となった。

免疫賦活剂の選択に当っては, 本研究での免 疫療法は，根治治療法後の再発転移防止を主目 的としているため，長期間の通院の可能性を問 題とした。即ち, $\mathrm{OK}-432$ は, 週 $1 \sim 2$ 回の通 院可能な患者, PS-K は, 頻回の通院困難な患 者に投与した。すでに述べた如く，S SMは， 患者または家族の希望により投与を行なった。

年令の選択も無作為に行なったが，免疫療法 群では平均56才, 対照群では平均50才となり, やや高令者に免疫賦活剂を使用する結果之なっ た（表 3 ). 
表 3 根治群・非根治群及び各種免疫療法群の症例数と平均年令

\begin{tabular}{|c|c|c|c|c|c|c|c|}
\hline & & 対 照 & O K -432 & P S-K & S S M & $\begin{array}{l}\text { 免疫療法群 } \\
\text { 合 計 }\end{array}$ & 総 \\
\hline \multirow{3}{*}{ 根治群 } & $\mathrm{n}$ & 14 & 9 & 10 & 4 & 23 & 37 \\
\hline & $\mathrm{M}$ & 49.9 & 55.6 & 56.1 & 61.0 & 56.7 & 53.9 \\
\hline & S.D. & 16.5 & 21.4 & 13.1 & 10.3 & 16.0 & 16.3 \\
\hline \multirow{3}{*}{ 非根治群 } & $\mathrm{n}$ & 0 & 11 & 3 & 4 & 18 & 18 \\
\hline & M & & 56.7 & 57.3 & 47.2 & 54.8 & 54.8 \\
\hline & S. D. & & 13.7 & 18.5 & 20.5 & 15.7 & 15.7 \\
\hline \multirow{5}{*}{ 計 } & $\mathrm{n}$ & 14 & 20 & 13 & 8 & 41 & 55 \\
\hline & $\mathrm{M}$ & 49.9 & 56.2 & 56.3 & 54.3 & 55.8 & 54.3 \\
\hline & S. D. & 16.5 & 17.5 & 13.6 & 16.8 & 15.6 & 15.9 \\
\hline & $\mathrm{n}$ & は症例数 & & & & & \\
\hline & M & は平均年令 & & & & & \\
\hline
\end{tabular}

IV. 検

1. 血清総補体価 $\left(\mathrm{CH}_{50}\right)$

$\mathrm{CH}_{50}$ の測定は, 西岡らの指導の下に, Mayer の50\%溶血法により測定した. 同方法による正 常値は, 種々検討した結果, 30〜45とした ${ }^{10)}$.

2. ツベルクリン皮膚反応（P P D反応，ツ 反応）

ツ反応は, 日本ビーシージー製の一般診断 用, 即ち $1 \mathrm{ml}$ 中にP P Dを $0.5 \mu \mathrm{g}$ 含有するす のを使用し，その $0.1 \mathrm{ml}$ 患者の前腕の皮内に 注射し，48時間後に判定した. 発赤の長径と短 径をノギスで測定して平均值を求め, $10 \mathrm{~mm}$ 末満 を陰性，10mm以上を陽性とした。

3. ツ反と $\mathrm{CH}_{50}$ による 6 期分類（以下 6 期 分類之略）

一般に担癌状態では，血清総補体価の高値之 細胞性免疫の低下傾向をみることが多い(7) 18)199 ${ }^{28)}$. 西岡ら ${ }^{5) 6)}$ は, 生体防禦にあたり細胞性免 疫之体液性免疫は独立しているあのではなく， 互いに関与し合って, 統一的に生体防禦機構を 形成して抢り，補体の上昇は細胞性免疫の低下 を補うという補償説を提唱した。さらに, 西岡 ${ }^{51}$ は，籊床上測定容易で定量化のしやすいツ反応 と $\mathrm{CH}_{50}$ を組合わせた 6 期分類を提唱した。 即ち, 同一患者の同時期のツ反応之 $\mathrm{CH}_{50}$ を測 定し, 縦軸に $\mathrm{CH}_{50}$, 横軸にツ反応をとり, そ
査

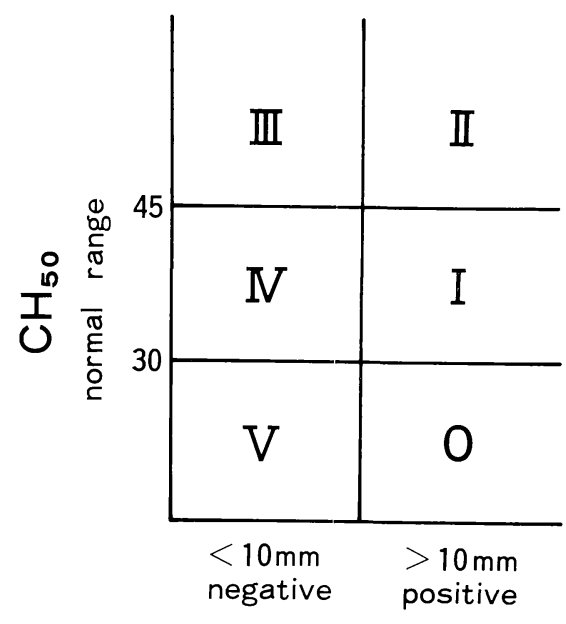

\section{Tuberculin reaction}

図 I ツ反応と補体による 6 期分類5)

れをプロットする. $\mathrm{CH}_{50}$ の正常域30〜45とツ

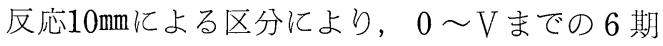
に分類している（図 1 )。通常，正常人は，ツ 反応陽性， $\mathrm{CH}_{50}$ が 30 45の間で I 期に入って いる．担癌者は，ツ反応陽性または陰性で， $\mathrm{CH}_{50}$ が高值を示すことが多く，【期またはIII 期に属するととが多い.

4. 末梢血リンパ球数

末梢血りンパ球数は, 末梢血の白血球数とそ 
の百分率より算出した，当院中央検査科におけ る白血球数の正常值は $4,500 \sim 7,000 / \mathrm{mm}^{3}$ であり, リンパ球の百分率は27〜 46\%であるため，実数 では1, 215〜3, 22J/ $\mathrm{mm}^{3}$ ととる. 一方, 当科に入 院の上, 声带ポリープの手術をうけた60名の患 者の術前検査汃ら，リンパ球数を算出すると $2,381 \pm 831 / \mathrm{mm}^{3}$ であった ${ }^{10)}$ 従って, 本研究にお いて，その正常值を $1,500 \sim 3,000 / \mathrm{mm}^{3}$ とた。

5. パラメーター測定時期について

$\mathrm{CH}_{50}$, ツ反応，末梢血リンパ球数の測定は 同一日に行ない，初診時に測定した值を「治療

\section{V. 成}

\section{1. 免疫療法の臨床成績}

1）根治群に招ける投与について（表 4)

癌根治治療法後に再発転移防止を目的として 免疫療法を行ない， 3 力月間は再発転移のない 23例について, 免疫賦活剂の検討を行なった。 その効果判定にあたり, 再発転移の有無を指標 とした. 本群における免疫賦活剂の投与期間は, PS-K 投与の 2 例を除き， 6 力月以上である.

a ） OK-432使用例飞ついて

OK-432使用の 9 症例は，2例に再発を認め たが， 7 例は再発なく経過良好である。

再発を認めた 2 例は, 投与後平均 8 力月で再 発を認めたが，その後にも投与を行なった。 1 例は，22力月使用して抢り，2 次加療後は再々 発むなく健在である。1 1 例は，途中再発をくり
前」值，照射治療中や制癌剂投与中や手術直後 に測定した值を「治療中」值とし，根治治療法 終了より一カ月以内の值を「治療直後」値とし た。兔疫賦活剤の投与は，癌の再発転移防止を 主目的として，通常根治治療法終了後 1 力月位 して投与を開始しており，それを投与する直前 の值を「免疫治療前」值とした。

以後の免疫学的パラメーターの測定は，1〜 3 カ月に 1 度行なった。データーの処理は， 3 力月単位の経時的变化として行なった。

\section{績}

かえし，他療法との併用をおこなったが，使用 後24力月して死亡した。再発を認めた 2 例は， 77才，75才と高令者であった。

再発もなく経過良好な 7 例は，最低12力月， 最高27力月，平低20力月の投与中であり，それ らの平均年令は，49.7才であった。

b ) PS-K 使用例について

PS-K 投与の 10 症例は， 5 例に再発または転 移を認め，5例が再発転移のない経過良好な症 例であった。

再発転移を認めた症例は，最低 5 力月，最高 10力月投与の時点において，再発または転移を 認めた．投与後約 6 力月して肺転移を認めた症 例 1 例は，投与後 9 カ月して死亡している. 再. 発のあった 5 例は，手術，放射線，化学療法な

表 4 免疫療法の臨床成績（根治群）

\begin{tabular}{|c|c|c|c|c|c|c|c|}
\hline \multirow{2}{*}{ 免疫賦活剤 } & \multirow{2}{*}{ 対象例数 } & \multicolumn{2}{|c|}{ 再発転移 } & \multirow{2}{*}{$\begin{array}{l}\text { 投与期間* } \\
\text { 尒均月数 }\end{array}$} & 軿 & 㷌 & \multirow{2}{*}{ 平均年令 } \\
\hline & & 有 無 & 例 数 & & 生 & 死 & \\
\hline \multirow{2}{*}{ O K -432} & \multirow[t]{2}{*}{9} & 無 & 7 & 20 & 7 & 0 & 49.7 \\
\hline & & 有 & 2 & 8 & 1 & 1 & 76.0 \\
\hline \multirow{2}{*}{ P S-K } & \multirow{2}{*}{10} & 無 & 5 & 14 & 5 & 0 & 59.2 \\
\hline & & 有 & 5 & 7 & 4 & 1 & 53.0 \\
\hline \multirow[t]{2}{*}{ S SM } & \multirow[t]{2}{*}{4} & 無 & 4 & 17 & 4 & 0 & 61.0 \\
\hline & & 有 & 0 & & & & \\
\hline
\end{tabular}

*投与期間は再発転移までの投与期間，または S52年12月までの投与期間の月数 
ぞの追加治療により，根治治療法後22力月から 26 力月経過した時点では再発転移を認めていな い. 再発後の投与は, 前述の死亡例を除き, 再 発を認めた時点で中止とした，再発転移例の平 均年令は53才である.

再発転移認めない経過良好な 5 症例の投与 期間については，途中投与中止が 2 例あり，1 例は 4 力月間投与で中止， 1 例は 12 力月投与に て中止しているが，中止後 8 力月および 2 力月 たった時点では再発転移を認めていない。のと り 3 例は 15 力から 21 力月間の投与を継続して いる。乙れらの経過良好な症例の平均年令は 59.2才であった.

c ） S SM使用例について

S S M使用の 4 症例は，最低14力月間，最高 23 力月間，平均 17 力月間の投与を行ない，なお 継続中であり，再発転移を認めていない。との 4 例の平均年.令は，61才であった。

2）非根治群における投与について（表 5) 癌根治治療法後に再発転移防止を目的とした 免疫療法を行なったにもかかわらず，根治治療 法後 3 力月以内に再発を認めた 18 例について兔 疫賦活剂の抗腫瘍効果を検討した。症例の均一 化が不可能であり，例数あ少ないのであるが， その判定基準として, 本研究では免疫賦活剂の 使用期間，即ち死亡までの期間を一応の基準之 した。 その投与期間は, 最低 3 カ月以上投与で きた症例において検討した。
なお，各種免疫賦活剂を単独に投与した 18 症 例の中には，他覚的にも一時的に軽快を示すよ うな症例を認めたが，明らかに腫瘍が小さくな るとか，腫演增大の停止を認めるような症例は 認めていない。

a ） OK-432使用について

$\mathrm{OK}-432$ 使用の 11 例の投与期間は，最低 5 力 月間，最高 10 力月間，平均 6.8 力月間使用して いる。 その平均年令は，56.7才であった。

b ） PS-K 使用例について

PS-K 使用の 3 例の投与期間は，最低 3 力月 間，最高 5 力月間，平均 4 力月間の投与を行な った。 その平均年令注，57.3才であった。

c ） S SM使用例について

S SM使用の 4 例の投与期間は， 1 例が使用 後 4 力月で脳出血死， 2 例が 15 力月， 1 例が 20 カ月投与後に死亡している. その平均年令は， 47.3才であった。

\section{3 ) 副作用}

O K-432の投与方法は種々あるが，本研究で 行なった筋注法は，長期間の投与を要する患者 には，便利であり，副作用も比較的少ないとさ れている。筋注法は，通常 $0.2 \mathrm{KE}$ より漸増し てゆくのであるが，40～50\%に発熱を認めた之 の報告が多い2012122). 本研究では，長期間投与 を20例に行なったが， 8 例に発熱を認めたが一 過性で，投与を重㸚てゆくと問題とならなくな った。なお，ペニシリンによると思われる全身

表 5 免疫療法の臨床成績（非根治群）

\begin{tabular}{|c|c|c|c|c|}
\hline \multirow{2}{*}{ 免疫賦活剤 } & \multirow{2}{*}{ 対象例数 } & \multicolumn{2}{|c|}{ 投与期間月数 } & \multirow{2}{*}{ 平均年令 } \\
\hline & & 最低～最高 & 平均 & \\
\hline $\mathrm{O} K-432$ & 11 & $5 \sim 10$ & 7.8 & 56.7 \\
\hline $\mathrm{P} \mathrm{S}-\mathrm{K}$ & 3 & $3 \sim 5$ & 4.0 & 57.3 \\
\hline S SM & $4^{*}$ & $4 * \sim 20$ & 13.0 & 47.3 \\
\hline
\end{tabular}

*1例は他病因死 
表 6 臨床代表症例

\begin{tabular}{|c|c|c|c|c|c|c|c|}
\hline \multirow[t]{2}{*}{ 症例 } & \multirow{2}{*}{$\begin{array}{l}\text { 氐, 名 } \\
\text { 年令, 性 }\end{array}$} & \multirow{2}{*}{$\begin{array}{l}\text { 病名 } \\
\text { 病理組織 }\end{array}$} & \multirow{2}{*}{ T NM分類 } & \multirow{2}{*}{ 根治治療 } & \multicolumn{3}{|c|}{ 免疫賦活剂 } \\
\hline & & & & & 種 類 & 維持量 & 投与期間 \\
\hline A & 75. 男 & $\begin{array}{c}\text { 上顎癌 } \\
\text { 扁平上皮癌 } \\
\end{array}$ & $\mathrm{T}_{3} \mathrm{~N}_{0} \mathrm{M}_{0}$ & $\begin{array}{l}\mathrm{BLM} \quad 135 \mathrm{mg} \\
\text { 上顎部分切除 } \\
\text { Linac } 6,000 \mathrm{R} \text { と } \\
\text { フトラフール } 3 \text { Tの併用 }\end{array}$ & O K -432 & $5 \mathrm{~K} \mathrm{E} /$ 週 & 14力月 \\
\hline B & 66. 男 & $\begin{array}{c}\text { 上顎嵒 } \\
\text { 扁平上皮癌 }\end{array}$ & $\mathrm{T}_{2} \mathrm{~N}_{0} \mathrm{M}_{0}$ & $\begin{array}{l}\text { BLM } 225 \mathrm{mg} \\
\mathrm{Linac} 2,200 \mathrm{R} \\
\text { 上顎部分切除 }\end{array}$ & P S-K & $3 \mathrm{~g} / \mathrm{\theta}$ & 21力月 \\
\hline $\mathrm{C}$ & 46. 男 & $\begin{array}{c}\text { 扁桃癌 } \\
\text { 扁平上皮癌 }\end{array}$ & $\mathrm{T}_{2} \mathrm{~N}_{3} \mathrm{M}_{0}$ & Linac $7,000 \mathrm{R}$ & S S M & \begin{tabular}{|l} 
ワクチン \\
$\mathrm{A}, \mathrm{B}$ 在隔 \\
日
\end{tabular} & 14力月 \\
\hline $\mathrm{D}^{*}$ & 77. 男 & $\begin{array}{l}\text { 煩粘膜癌 } \\
\text { 碉平上皮癌 }\end{array}$ & $\mathrm{T}_{2} \mathrm{~N}_{0} \mathrm{M}_{0}$ & $\begin{array}{l}\text { Linac } 6,000 \mathrm{R} \\
\mathrm{B} \mathrm{LM} \quad 75 \mathrm{mg}\end{array}$ & O K -432 & $5 \mathrm{KE}$ /週 & 7 力月 $* *$ \\
\hline
\end{tabular}

*再発例

**再発までの投与期間

の発疹を認めた症例が 2 例あり，投与を中止し ている.なお，PS-K 投与例， S SM投与例飞 は著明な副作用は認めていない。

\section{4）咟床代表例}

根治治療法後に免疫賦活剂の投与を行なって も，再発転移を認める症例は少なくない。しか し，個々の症例を検討すると，その投与により 臨床的, 免疫学的パラメーターより見て有効之 思われる症例あある。そこで臨床経過上代表的 な 4 症例をとりあげ，個々の症例を 6 期分類を 中心に検討した。

臨床代表 4 例の病名, 治療概略は表 6 亿示す 如くである。症例 A, B, C は経過良好例, 症例 $\mathrm{D}$ は再発例で，この 4 例の 6 期分類を示したも のが図 2 図 5 である。なお，図 2 〜図 5 の点 線は免疫賦活剂投与前, 実線は投与後を示して いる。

\section{a ) 症例 A}

症例 $\mathrm{A} は ， \mathrm{OK}-432$ 使用の経過良好例であ る。根治治療法終了後約 1 力月してOK-432を 単独に投与を行ない，一部腫演の残存を思水せ る部分をいわゆる局所清掃による外来治療を続 け，腫瘍を認めなくなった症例である。6 期分
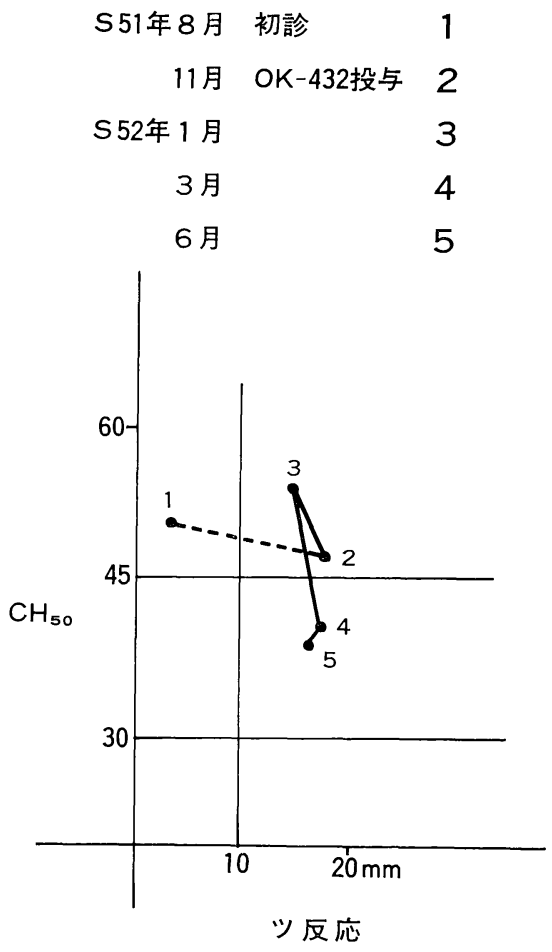

図 2 症例 $\mathrm{A}$ の 6 期分類

類上，初診時はIII期，根治治療法後即ち $\mathrm{OK}^{-}$ 432投与時には【期に入り，現在 I 期の正常域 に入り安定している(図2). 


$\begin{array}{rrr}\text { S50年5月 } & \text { 根治治療後10ヶ月 } & 1 \\ \text { 11月 } & & 2 \\ \text { S51年 3月 } & \text { PS-K 投与 } & 3 \\ \text { 4月 } & & 4 \\ \text { 12月 } & 552 \text { 年6月 } & 6\end{array}$

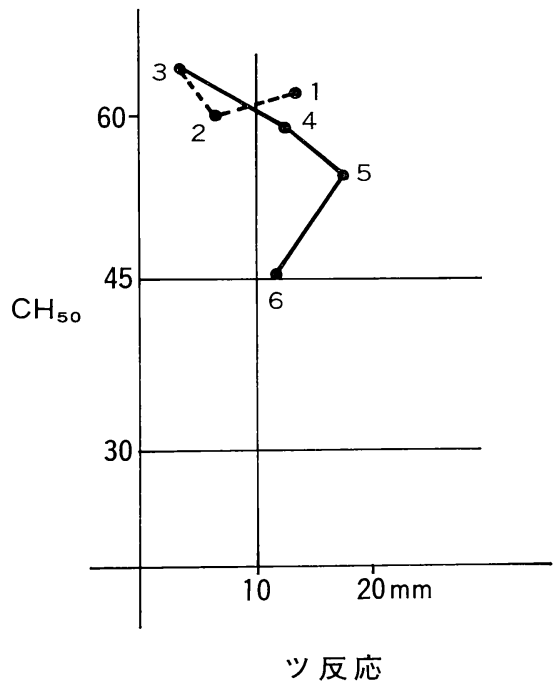

図 3 症例 $\mathrm{B}$ の 6 期分類

b) 症例 $\mathrm{B}$

症例 Bは, PS-K 使用の経過良好例である。 根治治療法後 10 力月の時点で, ツ反応が陽性で 6 期分類上【期にあったあのが，ツ反応の陰性 傾向を示しIII期に入ったので PS-K を投与し た。投与後約 1 力月して，ツ反応陽性となって II期に入り，さらにI期に動いている症例であ る。なお，PS-K 内服後より，自覚的に食欲六 進之感冒罹患が少なくなった（図 3 ).

c ) 症例 C

症例 C は，S S M使用の経過良好例である. 本症例は, 腫瘍の進展が $\mathrm{T}_{2} \mathrm{~N}_{3} \mathrm{M}_{0}$ で, Linac 総量 7,000R照射の時点ではなお両頸部リンパ 節を触知し，舌咽神経痛様の疼痛を訴えていた． この時点で 6 期分類上は I 期に入っていたが, 本人の希望により S S M投与を行ない, 使用後

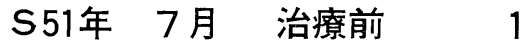 \\ 9 月 SSM投与 2 \\ 52年 3 月 3 \\ 6 月 4}

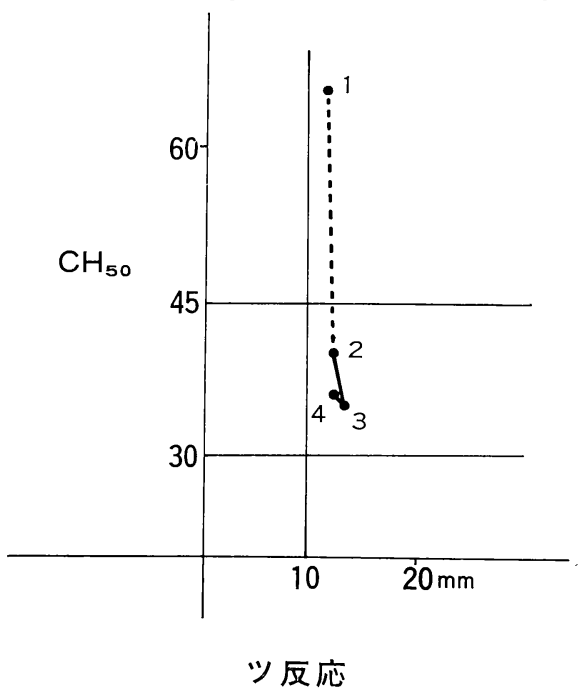

図 4 症例 $\mathrm{C} の 6$ 期分類

$3 \sim 6$ 週にて疼痛がとれると同時に全身状態が よくなり，頸部りンパ節むしだいにふれなくな った症例である(図 4 ).

d ) 症例 D

症例 Dは，OK-432 を使用したが，再発を認 め, さらに放射線と化学療法の追加治療により 経過のよい症例である。初診時は 6 期分類上の III期に位置し，初回治療により 時軽快中はI 期に入るか，再発を認める頃より 再びா期に入っている，特にこの症例では，臨 床的に再発を認めた時期よりも $\mathrm{CH}_{50}$ が高くな った時期の方が早く, $\mathrm{CH}_{50}$ の免疫学的パラメ ーターとしての鋭敏さを示している（図 5 ).

以上， 4 症例の臨床代表例の臨床経過之 6 期 分類を示したが，経過がよいと 6 期分類上を時 計回りに動き，再発などを認め経過不良となる と, 反時計回りに動くことを示している. 


$\begin{array}{rll}\text { S50年10月 } & \text { 初診 } & 1 \\ \text { 11月 } & \text { Linac照射中 } & 2 \\ \text { 12月 } & & 3 \\ \text { S51年2月 } & \text { OK-432開始 } & 4 \\ \text { 3月 } & & 5 \\ 4 \text { 月 } & & 6 \\ \text { 6月 } & & 7 \\ \text { 8月 } & \text { 再発を認む } & 8 \\ \text { 9月 } & \text { Linac再照射 } & \\ \text { S52年1月 } & & 9 \\ \text { 6月 } & & 10\end{array}$

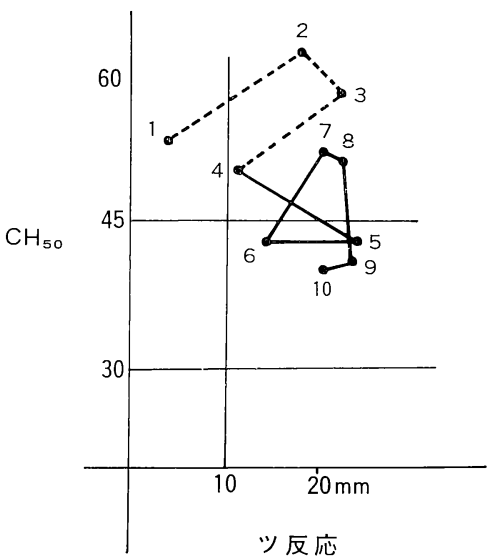

図 5 症例 D 6 期分類

表 7 臨床経過と血清補体価

\begin{tabular}{|c|c|c|c|c|c|c|c|c|c|}
\hline & & & 治療前 & 治療中 & 治療值後 & $2 \sim 4$ 力月 & $5 \sim 7$ 力月 & $8 \sim 10$ 力月 & 11〜13力月 \\
\hline & & $\mathrm{n}$ & 6 & 9 & 8 & 5 & 8 & 8 & 4 \\
\hline & & M & 51.3 & 61.8 & 59.8 & 47.4 & $44.3^{*}$ & 46.1 & 46.3 \\
\hline & & S.D. & 3.9 & 13.7 & 15.1 & 5.1 & 5.3 & 12.7 & 5.0 \\
\hline & $\begin{array}{l}\text { 経 } \\
\text { 過 }\end{array}$ & $\mathrm{n}$ & 8 & 6 & 10 & 13 & 13 & 12 & 5 \\
\hline & 良 & M & 49.8 & 53.0 & 49.4 & 45.9 & 44.2 & 41.3 & 42.4 \\
\hline & $\begin{array}{l}\text { 湧 } \\
\text { 群 }\end{array}$ & S.D. & 10.8 & 9.6 & 8.8 & 8.4 & 6.7 & 10.4 & 5.9 \\
\hline 兔 & 再 & $\mathrm{n}$ & 4 & 4 & 6 & 5 & 7 & 6 & \\
\hline 療 & 転 & M & 51.5 & 52.3 & 48.8 & $44.6^{*}$ & 49.7 & 54.7 & \\
\hline 法 & $\begin{array}{l}\text { 移 } \\
\text { 群 } \\
\end{array}$ & S.D. & 2.8 & 10.0 & 6.0 & 4.7 & 5.1 & 15.5 & \\
\hline & 韭 & $\mathrm{n}$ & 3 & 4 & 7 & 9 & 4 & 4 & \\
\hline & $\begin{array}{l}\text { 根 } \\
\text { 治 }\end{array}$ & M & 57.3 & 55.2 & 53.3 & 52.1 & 56.1 & 54.8 & \\
\hline & & S. D. & 8.7 & 9.8 & 7.8 & 6.5 & 1.5 & 12.7 & \\
\hline
\end{tabular}

*印は治療前值との間に $\mathrm{T}$ 検定 $(\mathrm{P}<0.05)$ 亿て有意差を認める.

\section{2. 免疫学的検查成績}

1) 臨床経過と免疫学的パラメーターの推移に ついて

免疫学的パラメーターにより免疫療法の効果 を評価するに当り，次の 4 群に分けて検討をお こなった。即ち，(1)最低 1 年以上再発転移を認 めず免疫賦活剂の投与を行なっていない「対照 群」，(2)免疫賦活剂を投与して最低 1 年以上再 発転移を認めない「経過良好群」，(3)免疫賦活 剂を投与して 3 力月間は再発転移を認めなかっ たが，それ以後に再発または転移を認めた「再
発転移群」，(4)免疫賦活剂を投与して 3 力月以 内に再発を認めた「非根治群」の 4 群に分けた。

なお表 7 ，表 8 の*印は，治療前の值之各時 期の值との差のT検定（ $\mathrm{P}<0.05 ）$ 亿て有意差 を認めるとと亦している.

a ) $\mathrm{CH}_{50}$ の推移, (表 7 , 図 6 ).

治療前の值は，4群之も正常より高值を示し 治療中の值はさらに高く, 治療直後の值は正常 に近づきはじめる。非根治群が，その後も50以 上の高值であるのに対し対照群, 経過良好群で は, 5〜 7 月月で正常域に入る. しかし, 経過 


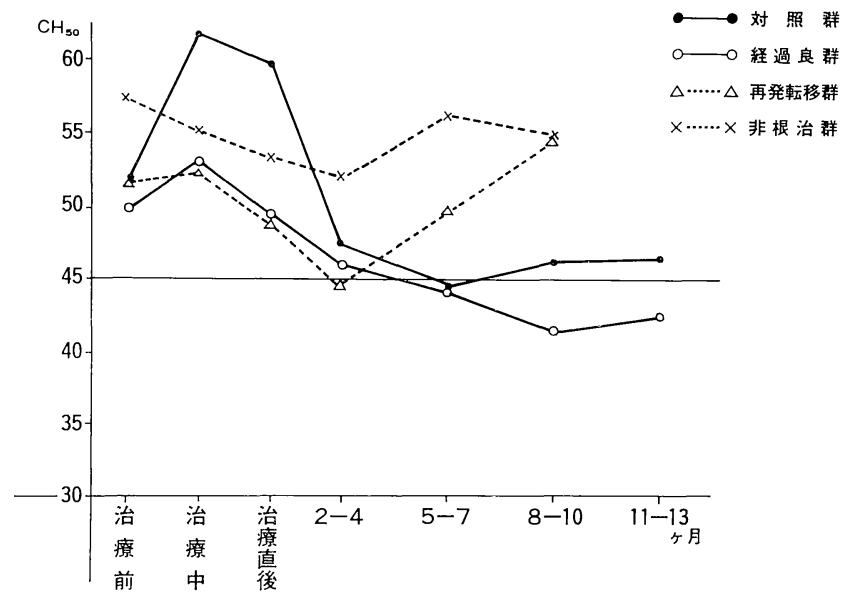

図 6 臨床経過と血清補体価

表 8 臨床経過とツ反応

\begin{tabular}{|c|c|c|c|c|c|c|c|c|c|}
\hline & & & 治療前 & 治療中 & 治療直後 & $2 \sim 4$ 力月 & $5 \sim 7$ 力月 & $8 \sim 10$ 力月 & $11 \sim 13$ 力月 \\
\hline \multirow{3}{*}{\multicolumn{2}{|c|}{$\begin{array}{l}\text { 対 } \\
\text { 照 } \\
\text { 群 }\end{array}$}} & $\mathrm{n}$ & 7 & 5 & 6 & 5 & 8 & 8 & 3 \\
\hline & & M & 23.1 & 21.8 & 12.3 & 35.3 & 26.9 & 24.6 & 33.8 \\
\hline & & S. D. & 15.4 & 18.2 & 11.9 & 21.6 & 20.7 & 15.0 & 24.9 \\
\hline \multirow{9}{*}{$\begin{array}{l}\text { 免 } \\
\text { 疫 } \\
\text { 療 } \\
\text { 法 } \\
\text { 群 }\end{array}$} & \multirow{3}{*}{$\begin{array}{l}\text { 経 } \\
\text { 過 } \\
\text { 良 } \\
\text { 恏 } \\
\text { 群 }\end{array}$} & $\mathrm{n}$ & 8 & 6 & 11 & 13 & 14 & 12 & 4 \\
\hline & & $\mathrm{M}$ & 14.3 & 15.1 & 13.6 & 16.2 & 15.7 & 14.3 & 13.5 \\
\hline & & S. D. & 5.0 & 12.5 & 9.3 & 10.4 & 9.4 & 6.3 & 3.9 \\
\hline & \multirow{3}{*}{$\begin{array}{l}\text { 再 } \\
\text { 発 } \\
\text { 軽 } \\
\text { 移 } \\
\text { 群 }\end{array}$} & $\mathrm{n}$ & 4 & 3 & 6 & 6 & 6 & 7 & \\
\hline & & $\mathrm{M}$ & 12.0 & 12.5 & 15.1 & 11.6 & 10.6 & 11.0 & \\
\hline & & S. D. & 16.2 & 10.9 & 12.7 & 9.8 & 7.6 & 9.2 & \\
\hline & \multirow{3}{*}{$\begin{array}{l}\text { 非 } \\
\text { 根 } \\
\text { 治 } \\
\text { 群 }\end{array}$} & $\mathrm{n}$ & 5 & 3 & 10 & 10 & 5 & 5 & \\
\hline & & $\mathrm{M}$ & 14.4 & 9.3 & 16.8 & 17.3 & 20.0 & 17.7 & \\
\hline & & S. D. & 11.0 & 8.5 & 18.6 & 15.1 & 16.1 & 15.7 & \\
\hline
\end{tabular}

良好群は正常域のまま推移しているが，対照群 では， 8〜10力月，11〜13力月の時点で約46を 示し, 正常域より少し高い值となっている。一 方, 再発転移群では, 根治治療法後, 一旦は正 常域に入るが，再発転移を認める5〜7力月の 時点と一致して高值を示し始め，8〜10力月の 時点では，さらに高値を示している.

b ) ツ反応の推移（表 8 , 図 7).

各 4 群のツ反応の経時的変化は著明ではな く, T検定において屯, 治療前の值との差に有
意差を認めるとはいえない。な抢，対照群にツ 反応が30〜 $50 \mathrm{~mm}$ 示す強陽性症例を 2 例含むた め，免疫賦活剂を使用している 3 群之同時期の 時点に扔いて，有意差を認める時期があった。

C) 末梢血リンパ球数の推移（表 9 , 図 8) 末梢血リンパ球数は, 根治治療法により減少 し，治療を終えると増加する傾向にある，特に 対照群や経過良好群にその傾向が見られたが, 対照群が11〜 13力月の時点で正常域にあるのに 対し, 経過良好群では $5 \sim 7$ 力月の時点ですで 


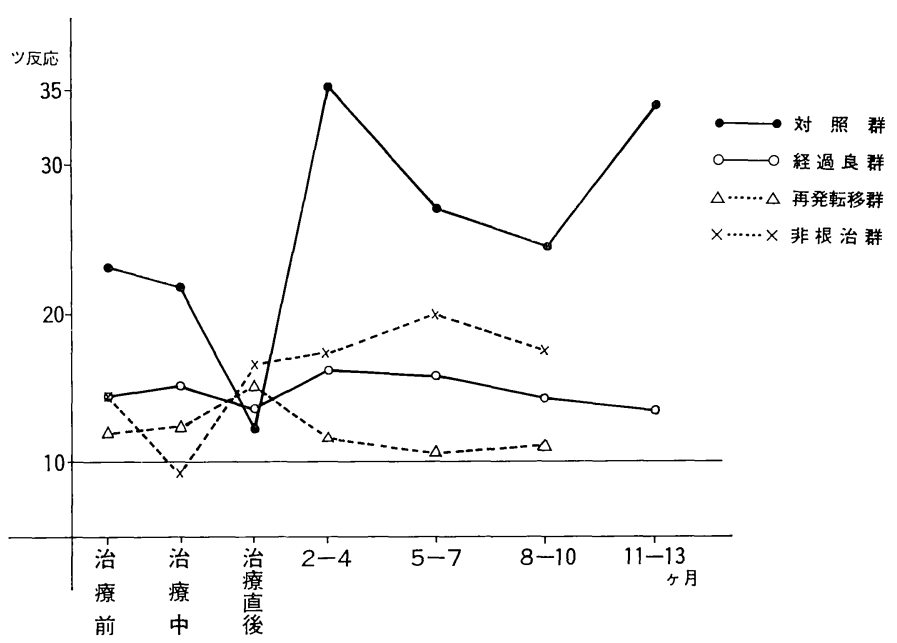

図 7 臨床経過とツ反応

表 9 臨床経過と末梢血リンパ球数

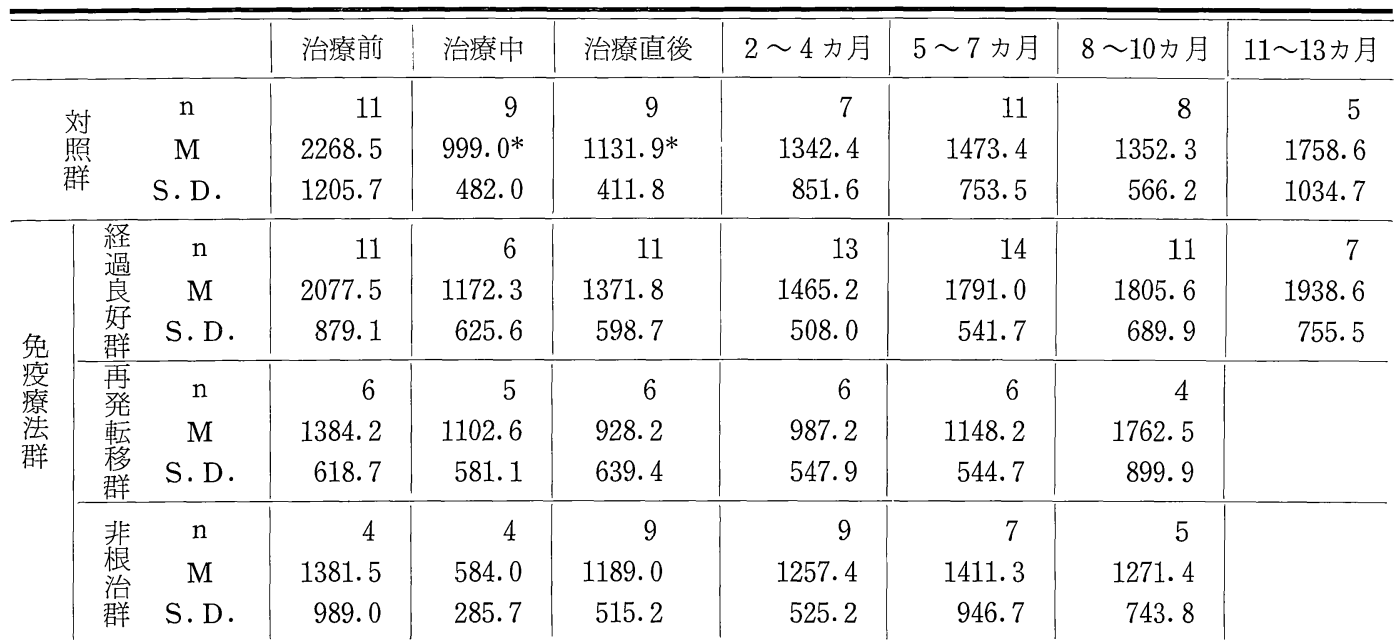

*印は 治療前值との間に $\mathrm{T}$ 検定 $(\mathrm{P}<0.05)$ にて有意差を認める.

に正常域に入っている。一方，再発転移群，非 根治群では，前 2 者に比して低い值を示し，全 経過を通してもお执と正常值以下の低い值を 示している.

2) 免疫賦活剂投与と免疫学的パラメーターの 推移について

免疫療法を行ない最低 1 年以上再発転移のな い経過良好群の16例のうち，経時的に免疫学的
パラメーターが測定できた15例において, 各種 免疫賦活剂投与別に免疫学的パラメータ一の推 移と対照群のそれとを比較検討した。なお，表 10 , 表12の*印は, 免疫治療直前の值之各時期之 の差のT検定 $(\mathrm{P}<0.05)$ にて有意差を認めるこ とを示している。また，対照群においては根治 治療法 1 力月前後の值との差を検定している.

a) $\mathrm{CH}_{50}$ の推移（表10）

$\mathrm{OK}-432$ 使用群が，投与後 $2 \sim 3$ 力月の時点 


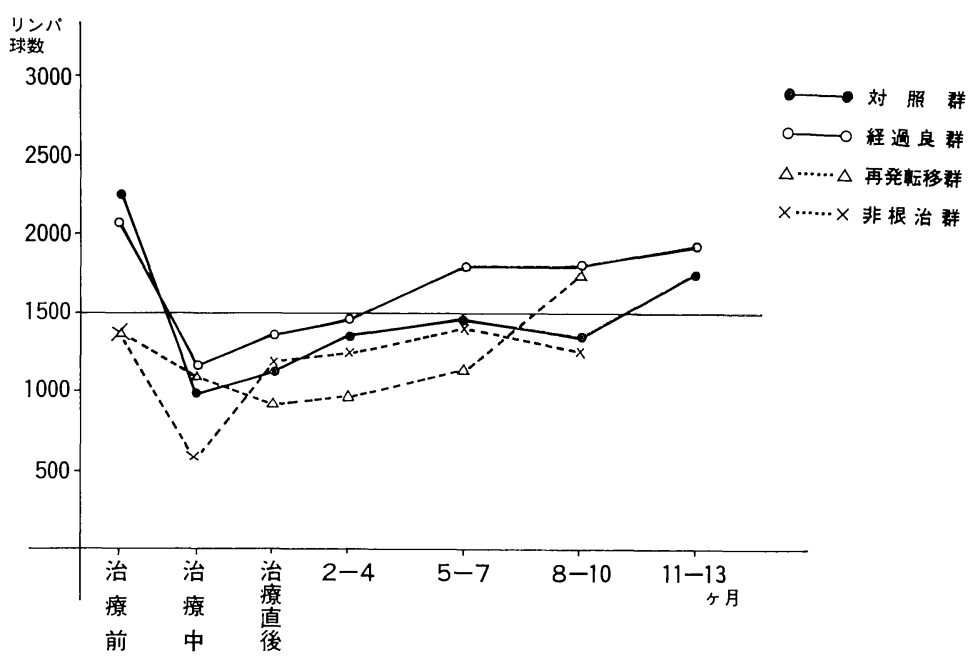

図 8 臨床経過と末梢血リンパ球数

表10 薬剤別にみた $\mathrm{CH}_{50}$ の推移

\begin{tabular}{|c|c|c|c|c|c|c|}
\hline & & 免疫治療前 & $2 \sim 3$ 力月 & $4 \sim 6$ 力月 & $7 \sim 9$ 力月 & $10 \sim 12$ 力月 \\
\hline \multirow{3}{*}{$\begin{array}{l}\text { 文 } \\
\text { 照 } \\
\text { 群 }\end{array}$} & \multirow{3}{*}{$\begin{array}{c}\mathrm{n} \\
\mathrm{M} \\
\text { S. D. }\end{array}$} & 14 & 5 & 8 & 5 & 9 \\
\hline & & 57.8 & $47.4^{*}$ & $44.3^{*}$ & $46.8^{*}$ & $45.9 *$ \\
\hline & & 13.6 & 5.1 & 6.8 & 7.6 & 8.9 \\
\hline \multirow{9}{*}{$\begin{array}{l}\text { 免 } \\
\text { 療 } \\
\text { 法 } \\
\text { 経 } \\
\text { 過 } \\
\text { 良 } \\
\text { 群 }\end{array}$} & O K $-432^{n}$ & 7 & 6 & 6 & 6 & 4 \\
\hline & 体田珜 M & 47.9 & 42.3 & $41.7 *$ & $41.0^{*}$ & 43.5 \\
\hline & 使用群 S.D. & 4.7 & 6.2 & 3.9 & 6.3 & 6.2 \\
\hline & $\mathrm{P} \mathrm{S}-\mathrm{K} \quad \mathrm{n}$ & 4 & 3 & 4 & 2 & \\
\hline & M & 50.5 & 49.3 & 46.3 & 43.5 & \\
\hline & 使用群 S.D. & 8.1 & 6.4 & 8.2 & 14.8 & \\
\hline & S SM n & 4 & 3 & 3 & 4 & \\
\hline & 使田群Ｍ & 47.5 & 49.0 & 46.0 & $40.8^{*}$ & \\
\hline & |使用群 & 16.4 & 13.5 & 9.6 & 16.0 & \\
\hline
\end{tabular}

*印は免疫治療前值との間にT検定（ $\mathrm{P}<0.05 ）$ にて有意差を認める.

で正常域に入る．PSK，S SM使用群は，7 〜 9 力の時点で正常域に入る. 一方，対照群 は，根治治療法後 $4 \sim 6$ 力月で一度正常域に入 るが，それ以後は46前後の值となっている。

b ） ツ反応の推移（表11）

ツ反応の免疫賦活剂使用後の変化は，著変を 認めるとはいえない。しかし，個々の症例を検 討すると，根治治療法後に陰転した症例は認め ず，陽転した症例が対照群では 2 例，O K-432
PS-K， S S M使用群では各 1 例であった。一 方, 㓌性のまま変化のない症例は, 対照群と $\mathrm{S}$ SM使用群に 1 例認めた.

C ）末梢血リンパ球数の推移（表12）

末梢血リンパ球数は，OK-432使用群で確実 に増加しており，10１2力月の時点では有意差 屯認めている．PS-K 使用群では，投与前の值 が2, 020/ $\mathrm{mm}^{3}$ と正常值を示しており，その後の変 化は認めない. S SM使用群は, 投与後漸増し 
表|| 薬剤別にみたツ反応の推移

\begin{tabular}{|c|c|c|c|c|c|c|}
\hline & & 免疫治療前 & $2 \sim 3$ 力月 & $4 \sim 6$ 力月 & $7 \sim 9$ 力月 & $10 \sim 12$ 力月 \\
\hline \multirow{3}{*}{$\begin{array}{l}\text { 対 } \\
\text { 照 } \\
\text { 群 }\end{array}$} & $\mathrm{n}$ & 13 & 5 & 7 & 9 & 6 \\
\hline & M & 23.3 & 32.8 & 33.7 & 29.1 & 27.3 \\
\hline & S. D. & 15.3 & 18.5 & 24.8 & 13.3 & 17.8 \\
\hline \multirow{9}{*}{$\begin{array}{l}\text { 免 } \\
\text { 疫 } \\
\text { 療 } \\
\text { 法 } \\
\text { 経 } \\
\text { 過 } \\
\text { 良 } \\
\text { 好 } \\
\text { 群 }\end{array}$} & $\mathrm{OK}-432 \mathrm{n}$ & 7 & 5 & 6 & 6 & 4 \\
\hline & 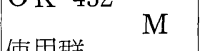 & 17.4 & 19.0 & 14.4 & 14.8 & 13.5 \\
\hline & 使用群 S.D. & 10.3 & 6.8 & 3.0 & 5.8 & 3.9 \\
\hline & $\mathrm{P} \mathrm{S}-\mathrm{K} \quad \mathrm{n}$ & 4 & 2 & 4 & 2 & \\
\hline & 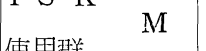 & 20.0 & 18.0 & 22.8 & 19.0 & \\
\hline & 使用群 S.D. & 12.5 & 10.5 & 14.4 & 2.8 & \\
\hline & S SM n & 4 & 2 & 4 & 4 & \\
\hline & M & 8.1 & 7.8 & 10.6 & 11.3 & \\
\hline & 使用群 S.D. & 8.0 & 11.0 & 7.3 & 7.7 & \\
\hline
\end{tabular}

表12 薬鼡別にみた末梢リンパ球数の推移

\begin{tabular}{l}
\hline \\
\hline
\end{tabular}

*印は免疫治療前值との間にT检定（ $\mathrm{P}<0.05 ）$ 亿て有意差を認める.

ており，4〜6カ月にて正常域に入っている.

\section{VI 考按}

現在臨床で施行されている癌免疫療法は前述 の Mathé や Morton が, 本邦では井沢ら ${ }^{23)}$ や吉崎ら ${ }^{24)}$ が行なっているような， B C Gをア ジュバントとして，腫瘍細胞と共存させて行な う能動的免疫療法屯行なわれているが，広く臨 床で実施されているのは非特異的免疫療法であ
る. 即ち, 非特異的免疫療法は, 本研究での投 与方法のように非特異的免疫賦活剂を担癌者に 投与することにより, 担癌者の低下している免 疫能を正常に戻して, 結局は特異的な免疫を期 待する方法である. しかし, いずれの免疫療法 においても, 投与時期, 投与量, 投与期間など 
の投与方法については未だ確立されていない. 本研究では，非特異的免疫賦活剂の投与によ り, 臨床面より見た効果, 兔疫学的パラメータ 一より見た効果，投与方法などについて若干の 考察をおこなった。

\section{1. 免疫療法の臨床効果}

現在の免疫療法は抗腫瘍作用が弱く, 免疫賦 活剂の単独効果はみられないかまたは効果を認 めることは少ない。

本砳究の目的の 1 つには, 非根治群に対して 免疫賦活剂の単独の投与により，腫瘍増殖の停 止や延命を期待したが，いずれの症例において む，はっきりとはその効果を認めるととができ なかった。

そこで根治群に执いて，主目的である再発転 移防止のため免疫賦活剤を単独に投与をおてな ったにもかかわらず再発転移を来した症例を中 心に問題点を考察した.

a ） $\mathrm{OK}-432$ 使用例について

$\mathrm{OK}-432$ 投与の 9 例のうち，2 例に再発を認 めたが，2 例とも高令者であり，75才の 1 例は 追加治療にもか力わらず再発して，投与 22 力月 後に死亡した，77才の 1 例は，追加治療により 健在である。OK-432の維持量は，前者が週 $3.0 \mathrm{KE}$ ，後者が週5.0K Eであった。

OK-432の作用は，宿主介在性に免疫を賦活 し, dose response は忘しいとされている。し 汃し，Kondo ら ${ }^{25)}$ は，非癌老令患者のうち細 胞性免疫が低下している患者10例に，週 $7 \mathrm{~K} \mathrm{E}$ の筋注により， $\mathrm{PHA}$ 皮内反応の増強を 9 例に 認めた。 それを週 $2 \mathrm{KE}$ に減少したところ， $\mathrm{P}$ $\mathrm{HA}$ 皮内反応は減少傾向を示し，使用中止によ り更に減少傾向を示したとしている.

木村 ${ }^{13)}$ は， O K-432 の筋注効果の持続期間 は投与後漸減してゆくけれどあ，1週間は持続 し，投与回数を重ねた方が効果が増強するとし ている.

本研究では, 維持量として週 $3 \sim 5 \mathrm{KE}$ の筋 注をおてなってきたが，今後は高令者免疫不全 者を中心に，週 $5 \mathrm{~K}$ E以上の筋注の長期間投与
を検討したい。

b ） PS-K 使用例について

PS-K は経口的に $3 \mathrm{~g}$ の投与を行なったが， 10 例中 5 例に再発転移を認めた。

再発転移例は，1例は肺転移を認め死亡し， 4 例は追加治療にて 1 年以上再々発を認めてい ない，投与は死亡した 1 例を除き，再発を認 めた時点で投与を中止している。再発転移につ いては根治治療法にも問題がないとはいえない が，一応症例を無作為に選んでいるととを考え ると， PS-K 使用例では再発の割合が高いと思 われる。

PS-K は腫瘍に対する直接作用を有するが， 宿主介在性に免疫を賦活する作用が主とされて いる，投与に関して，腫瘍移植実験では，宿主 介在性の抗腫瘍効果は癌移植前30日以前投与群 にもみられ，かなり長い間宿主に影響を与えて () ${ }^{14)}$.

本研究における PS-K 投与例の再発転移例 より，PS-K の投与方法，経口であるための吸 収の不確実性の問題，また根治治療法直後の

PS-K の単独投与には，症例によっては問題が あると推測された。

c） S SM使用例について

S SM投与例では，最低14力月投与している が再発転移を認めていない。

丸山 ${ }^{16)}$ は，ヒト結核菌の抽出物質である S S Mは実験動物腫瘍には無効であるが，臨床レベ ルでの判定では, 癌患者490例中241例に有効例 を認めたと報告している。

B C G 療法が，実験腫瘍や臨床においても効 果が認められているのは周知の事実である。一 方，S SM投与の実験腫瘍に対する有効性を認 める報告は少ない。近年，藤田ら ${ }^{26)}$ は，Sarcoma 180 (固型) マウス移植癌に対して, S S $\mathrm{M}$ の腹腔内投与により癌増殖の抑制効果を認め たと報告. 佐藤 ${ }^{27)}$ は抗原性の高いラット癌腹水 にS SMを投与し，特に皮下と筋肉内投与にお いて延命効果を認めたと報告している.

通常，実験腫瘍は自然発生腫瘍より抗原性が 
高く，もっと多くの客観的データが必要である と考えられる. 特に，S SMに関しては，社会 的見地加らも, 実験腫瘍に対する効果や免疫学 的パラメーターによる判定が必要であり，今後 の検討を待たねばならない，

しかし，患者や家族にとっては，癌は不治の 病いという考えから本剂が精神的支えとなる場 合むある。

\section{2. 免疫学的パラメーターの推移}

すでに述べた如く，人の免疫監視機構は体液 性免疫之細胞性免疫に大別され，その両者が互 いに総括的，協調的に反応し合って生体防禦機 構を形成している。腫瘍免疫は細胞性免疫が中 心的な役割をはたしていると考えられているた め，パラメータ一も細胞性免疫に関するあのが 多い，癌患者の免疫能を知るため, 現在のと乙 ろなるべく多くのパラメーターの測定により， 総合的に判定するのがよいとされている。しか し, 臨床に执いては限りがあり, 本研究では癌 患者に対する負担が少なく，しかす定量化しや すいパラメーターとして, 細胞性免疫の面より ツ反応，体液性免疫の面より $\mathrm{CH}_{50}$ をとりあ げ，更にツ反と $\mathrm{CH}_{50}$ による 6 期分類を使用し た。また，補助検查として末梢血リンパ球数を 測定した。

一方，対象を臨床経過により前述のように対 照群，根治群，非根治群に分け，さらに根治群 を経過良好群と再発転移群に分け，乙の4 群に おける免疫学的パラメーターの経時的推移を観 察し，パラメーターの意義につき検討した。

\section{a) $\mathrm{CH}_{50}$}

本研究に求ける癌患者の $\mathrm{CH}_{50}$ の変化は, 治療前は高く，治療によりさらに高くなり，治 療直後は正常に近づく，その後，対照群は 5 〜 7 力月にて正常域に入るが， $8 \sim 10$ 力月以降は 46前後の值となっている. 経過良好群は $5 \sim 7$ カ月以降も正常域のままであり，再発転移群は 一旦正常域にあるが，再発転移が認められ，そ れが進展すると共に高值を示す。担癌者である 非根治群では， $\mathrm{CH}_{50}$ は高值のままである。
$\mathrm{CH}_{50}$ の高值を示す疾患には, 炎症, 慢性ア レルギー疾患，悪性腫瘍などが挙げられる，癌 に関しての報告のうち, 河村ら ${ }^{28)}$ は肺癌の腫瘍 の大きさと $\mathrm{CH}_{50}$ とが相関するととを示してい る. 中島 ${ }^{10)}$ は, 頭頸部癌患者の治療経過に㧊け る $\mathrm{CH}_{50}$ を検討し, 治療前群は正常上り高く, 治療中群はさらに高く, 筧解群, 5 年生存者群 では正常に近づくが，逆に再発転移群は高值を 示すと報告している.

一般に補体の高值の原因は, 炎症または組織 破壊による補体産生の亢進が考えられている. 肺癌では, 癌病変部での補体の消費が推測され 癌の細胞膜には $\mathrm{C}_{3}, \mathrm{C}_{4}$ の沈着む認められてい $る^{28)}$. 橘は ${ }^{29)}$, 補体が直接細胞破壊へ導くこと や， $\mathrm{C}_{3}$ リセプターを有するリンパ球やマクロ ファージの作用を受ける可能性のあるととを示 唆するとしている.

Sakamoto, Nishioka ${ }^{30)}$ は, ラットへの $\mathrm{AH}$ 130 肝癌の生着実験に执いて, Corynebacterium (C. murium, C. renale) の感染 7 日後 の群に肝癌生着防止を認めている。乙のととは Corynebacterium の直接作用であなく，それ に対する抗体によるすのであなく，免疫系のう ち補体活性の上昇によるものであると報告して いる。

以上, $\mathrm{CH}_{50}$ の推移は臨床経過とよく相関し ており, 補体の抗腫瘍作用屯考元合わせる之, その経時的測定は，予後判定や免疫療法の評価 のパラメーターとして有用であると考えられ る.

b ）ツ反応

ツ反応は細胞性免疫能の把握に有用な遅延型 過敏皮㪭反応の一つで，担癌者にはその低下が 見られ, 癌の病期が進展していると, その反応の 陰性化率が高くなるとされている ${ }^{3132)}$. 中島 ${ }^{10)}$ は，頭頸部癌患者の 5 年治癒群のッ反応の陽性 率は $91 \%$ ，担癌者のそれは $56 \%$ で，治療中やそ の直後では治療前より反応が低くなると報告し ている.

伊東 ${ }^{33)}$ の頭頸部悪性腫瘍患者 242 例の 7 種 
遅延型皮膚反応（P P D, P HA，カンジダ， SK-SD，ムンプス，水痘，DNCB） 飞つき 検討した報告では，腫湯の進展子皮膚反応飞相 関を認めた。しかし，1年後の予後につき検討 した結果では, 皮膚反応正常群, 不全疑い群, 不全群それぞれの再発のない症例の割合は, 67 \%，62\%，56\%であり，遅延型皮䖉反応により ある程度の予後を知ることはできるが，限界が あるとしている。

本研究では, 治療経過により 4 群に分けてッ 反応の経時的変化， 4 群の差を検討したが, 著 明な変化や差を認めるとはいえない，乙のとと は，ツ反応陰性を $10 \mathrm{~mm}$ 未満にしている一方，ツ 反応陽性 $20 \mathrm{~mm}$ 以上屯単純計算に括いて算出し, 比較している点にも問題があり, 特にツ反応強 陽性の検討を要すると思われる。 また, 本研究 のように根治治療法後, 即与腫場が無いか, 少 ない場合には, ツ反応む比較的陰性化しにくい と考えられる。つまり, ツ反応は, 腫瘍量や病 期とは相関するが，根治治療法後の再発転移な どの経過を見るには鋭敏なパラメーターとはい えないともいえる. しかし, 西岡らの 6 期分類 や補償説を考えると, 個々の症例におけるツ反 応の陽転や陰転を経時的に追うことは，予後を 知るのに有用といえる.

\section{c ） 6 期分類}

担癌生体では，一般に補体系の活性化に対し て, ツ反応の低下が認められる。前述のように 細胞性免疫の面, 体液性免疫の面より統一的に 検討するパラメーターとして，6 期分類は意義 があると思われる。しかし，前述のようにッ反 応を多数症例の平均值として示すととには問題 があり，乙れによるとI 期，【期が中心となり， 6 期分類は $\mathrm{CH}_{50}$ の推移を見るとととなる.

従って, すでに示した臨床代表例のように, 個々の症例についての臨床経過と免疫能の変化 を検討することが必要であり，それには 6 期分 類は理解しやすく便利と考えられる.

d ) 末梢血リンパ球数

折田 ${ }^{34)}$ は, 肺癌, 子宮癌, 乳癌での予後と末
梢血リンパ球数に相関関係があるとし, 渡辺ら 35) は, 胃癌の病期の進展に伴ない末梢血リンパ 球数百分率の低下があることを報告している. 中島 ${ }^{10)}$ は, 頭頸部癌患者に捛いて, 5 年生存者 は正常人と変らないが, 担癌者や治療後には末 梢血リンパ球数の低值を示すとしている.

本研究での 4 群の経時的変化を見ると, 治療 中や治療直後の值は, 治療前の值より低いが, 治療後は漸増してくる.

根治治療法により減少した末梢血リンパ球数 は，免疫賦活剂を使用した経過良好群では，他 群之の有意差は認めないが, 早く正常域にもど り, 漸増している.

従って, 根治治療後のパラメーターとして は，末梢血リンパ球数は鋭敏に変化するとはい えないが，長期間の経時的推移に㧍いては，あ る程度てれにより予後を知るととができ, 補助 的なパラメーターとしては有用と考えられる。

\section{3. 免疫学的パラメーターと免疫賦活剂}

現在の免疫賦活剂は, 抗腫瘍作用が弱く, 免 疫賦活の作用機序屯確立されておらず，その上 に担癌体では免疫能は多くの要素により修飾さ れ, 体内の免疫反応屯腫瘍の成長之共に変化す ると考えられるため, 担癌者に対する免疫賦活 剂の治療効果の判定は困難である. 従って本研 究では, 根治治療法後に免疫賦活剂の投与を行 ない, 最低 1 年以上再発転移を認めない経過良 好群と免疫賦活剂の投与を行なわないで, 最低 1 年以上の再発転移を認めない対照群につき, 免疫学的パラメータ一の推移より, その効果を 検討した。

a) $\mathrm{CH}_{50}$ より見た免疫賦活剂

補体系の反応は, classical pathway と呼ば れる反応経路と alternate pathway と呼ば れる反応経路に分けられている. 前者は抗原抗 体の複合物により $\mathrm{C}_{1} \sim \mathrm{C}_{9}$ の 9 成分の反応によ って補体の生物学的活性がひき打てされる。一 方, 後者は, ザイモザン, イヌリン, グラム陰 性菌の Lipopolysaccharides (L. P. S.), レ ンチナンなどの多糖類, コブラ毒の因子（CV 
F)， $\operatorname{Ig} \mathrm{A}, \operatorname{IgE}$ により $\mathrm{C}_{1} \mathrm{C}_{4} \mathrm{C}_{2}$ の反応経路を 介さずに直接 $\mathrm{C}_{3}$ 以下を活性化するとされてい る ${ }^{36)}$. 本研究で使用している PS-K, SSM む 同じ多糖体であり，宿主介在性の免疫賦活剂で あるととを考えると, 補体系, 特に alternate pathway の活性化があるであろうと推測さ れる. OK-432 に関しては，西垣ら ${ }^{37)} は ，$ 免疫不全の高令者に OK-432 の筋注により， alternate pathway の活性化を認める報告を している.

表10における $\mathrm{CH}_{50}$ の推移を比較検討してみ ると, 対照群では 7 ～9月, 10〜12力月では 46前後の值であるのに対して, O K-432使用群 は，2３カ月にてすでに正常域に入り，その 後も正常域内にて安定した值を示している.

PS-K 使用群， S S M使用群では OK-432 使 用群と比べて下りが遅いが， 7 〜 カ月に抽 ては正常域にある。

以上より，いずれの免疫賦活剂も対照群に 比べ確実に $\mathrm{CH}_{50}$ を低下せしめ，半年後には 正常域に入っており，その有効性が推測され た。

\section{b ）ツ反応上り見た免疫賦活剂}

前述のように担癌者は陰性化している率が高 いとされるが，ッ反応により予後を推測するに は限度がある．また前述の如くツ反応の平均值 の推移を見るととは問題もあり，著変も少ない ので，根治治療法後に免疫賦活剂を投与した後 の陽転例数につき比較検討するのが妥当と考え られた。

木村ら ${ }^{38)}$ は，OK-432の宿主介在性作用の検 討において，OK-432が担癌ハツカネズミの遅 延型皮膚反応の低下防止をするとしている。

Kondo ${ }^{25)}$ は，細胞性免疫の低下した非担癌老 命患者10例に，OK-432 を週 $7 \mathrm{~K} \mathrm{E}$ 筋注した之 ころ, 3 力月以内に 9 例の $\mathrm{P} \mathrm{HA}$ 皮内反応の増 強を認めたが，ツ反応では 3 例が陽性化し，そ のうち 1 例が $\mathrm{K}$ K-432投与中止により陰転した と報告している。

中野 ${ }^{399}$ は，マウスの Sarcoma-180 担癌マ
ウスでは，遅延型皮膚反応が皮下移植後 3 週後 に沶いて，無処置正常マウスのそれに比して著 明に低下している。 ての移植 3 週後に癌を切除 すると, 遅延型皮膚反応は回復し, 切除後約 3 週間で正常レベルに達した。一方，癌切除の翌 日より PS-K を 1 日 $1,000 \mathrm{mg} / \mathrm{kg}$ を連日経口投 与すると, 切除 1 週目には正常レベルに回復し たと報告している。

ここでは, 経過のよい症例群に执いて検討し ているためか，陰転を認めた症例はない，一方 陽転例数は，OK-432使用群では 1 例中 1 例, PS-K 使用群では 1 例中 1 例, S S M 使用群で は 2 例中 1 例，対照群では 3 例中 2 例に陽転を 認めている。いずれの症例む根治治療法後 6 力 月以内に陽転しており，陽転までの期間や陽性 率については症例も少なく検討できない。

c ）未梢血リンパ球数と免疫賦活剤

O K-432の投与により, 進行性の悪性腫瘍患 者や化学療法を併用している担癌者に拈いて あ, 末梢血りンパ球数の増加を認めるという報 告は多い20122) 46).

小谷野 ${ }^{40)}$ は，胃癌患者 16 例の胃切後に，PS$\mathrm{K}$ を 1 日 $6 \mathrm{~g}$ 経口投与と化学療法の併用を行 なった症例では，末梢血りンパ球数は投与前に 比べて有意差を示さなかったが，PHAによる blastoid transformation in vitro は有意に 上昇したと報告している。そして，PS-K は T-cell の機能六進を招来させるが，リンパ球 全体の数は増加させないとしている.

本研究では，PS-K 使用群では，投与前より 正常域にあるためか，変化がないといえる。

OK-432 使用群，S S M使用群では，末梢血り ンパ球数の漸增が見られるが，同時期における 対照群とに有意差があるとはいえない。しかし 末梢血リンパ球数の数量的増加傾向より見る と, OK-432の有効性が推測された。

\section{4 . 免疫療法における投与法の検討}

癌の免疫療法は癌治療の第四の治療法として 脚光をあびているが，現在のところ癌治療の主 役とはなりえない。 
癌の免疫療法は腫瘍量により限界があり，そ れが効果的に行なわれるには，腫瘍量が小さい こと, 腫瘍の抗原性が高く, 宿主免疫反応性が 正常に䡃くことが必要とされている ${ }^{41)}$.

本研究に氺いても, 根治治療法後の非担癌状 態となったと思われる症例に免疫賦活剂の単独 投与を行なったが，再発転移症例を認めた。根 治治療法や免疫賦活剂の投与方法に問題がない とはいえないが，生来癌に対する免疫す持つ之 考えられるのに癌細胞の増殖を許している.

その原因を免疫学的立場より考察すると, 免疫学的寛容 immunological tolerance, 免疫機能が先天的, 後天的に欠陥があるために おこる非特異的免疫無応答, (3)免疫応答遣伝子 の欠如, (4) Suppressor T-cell による Effector T-cell の抑制，(5)抗原抗体複合物 immune complex である阻止因子 blocking factor, その他, 抗原の離脱や腫瘍細胞からの免疫 抑制因子などがあげられる29).

そこで，乙こでは Prehn ${ }^{42) 43)}$ の免疫制激 の問題について述へ，投与法につき検討した い.

免疫学的促進 immunological enhancement は，比較的大量の抗体は癌細胞の増殖を抑制す るが，比較的少量の抗体は癌細胞の増殖を促進 を意味するが，とのような宿主の免疫抑制に働
く主因子は, 抗原抗体複合物 immune complex で，これを阻止因子 blocking factor と呼んで いる. 一方, $\operatorname{Preh}^{42) 43}$ は，細胞性免疫を担当 しているリンパ球にあ同じ現象がおこるとし， 腫瘍増殖機構として免疫刺激 immunostimulationを仮説として提唱している. 即ち, 腫瘍 特異的免疫が弱ければ，かえって感作リンパ球 が腫瘍増殖を促進するという。乙の問題につい て橘 ${ }^{29}$ は，乙の仮説が正しいなら癌治療での考 えも変るととも考元られ，今後十分に検討す心 き問題であるとしている.

実際の臨床での癌治療は，やはり手術，放射 線, 化学療法が主となる。乙れらにより腫瘍量 を少なくし，またそのため一部腫瘍細胞の破 壊, 変性により抗原性の高まるととも考えられ る ${ }^{44)}$. 一方では, 放射線や化学療法により免疫 能の低下がおこりうる。

以上，乙れらのととを考え合わせると，従来 の癌治療之免疫療法を同時併用するととの有用 性が考えられ, 実際の臨床でむ, 癌治療汶対す るいわゆる免疫化学療法の有効性を認める報告 あ多( 45) 46) 47). しかし，免疫療法を併用する場 合, ぞの免疫賦活剤を, どの時点で, どの治療 と組み合わせて损てなうのが適当か今後の問題 としたい.

\section{VII ま と}

近年, 癌の第 4 の治療法として, 免疫療法が注目されている.

昭和 49 年10月より昭和 52 年 12 月までの間に慶大耳鼻科において治療をおてなった頭頸部癌患者 55 症例のうち, 癌根治治療後に免疫賦活剂（OK-432, PS-K, S SM）を長期間投与した免疫療法 群と投与しない対照群に分け，臨床経過と免疫学的パラメーターより免疫療法につき検討をおこな った. 免疫学的パラメータ一の推移より免疫賦活剂を検討するに当り, 対象を一定期間の臨床経過 観察の後に, 対照群, 非根治群, 根治群に分け, さらに根治群の再発転移の有無により, 経過良好 群と再発転移群の 4 群に分けて検討した.

なお，免疫賦活剂の投与は，再発転移防止を目的として癌根治治療法終了後より投与行なった が， 根治治療法後 3 力月以内に再発を認めた非根治群では腫瘍の縮小や増殖停止を目的として投与 を行なった。

1. 免疫療法の臨床効果

1) 根治群での O K- 432 投与の 9 例中 2 例に再発を認め, PS-K 投与の 10 例は 5 例に再発または 
転移を認め，S SM投与の 4 例には再発転移は認めていない.

2 ）非根治群の18症例中，いずれの免疫賦活剂の投与においても，腫瘍の縮小または増殖の停止 は認めなかった。

3 ）副作用については，OK-432の長期間投与（筋注法）の20例中 8 例に一過性の発热を認めた が，治療を継続し得た。なお，PS-K 投与例， S S M投与例には著明な副作用は認めなかった。

2 . 免疫学的パラメーターの検討

癌根治治療法後の臨床経過と免疫学的パラメーターとの関係を前述の 4 群に分けて検討した。

1) $\mathrm{CH}_{50}$

補体には抗腫瘍作用むあると考えられ， $\mathrm{CH}_{50}$ は臨床経過と相関しており，担癌状態，非担癌状 態を示す鋭敏なパラメーターと考えられた。

2）ツ反応

ツ反応は，腫瘍量や病期とは比例するが，本研究のように根治治療法後の再発転移を見るには鋭 敏とはいえない。しかし，個々の症例に扣いて陽転や陰転を経時的に観察するととは，予後を知る のに有用と考えられた.

\section{3） 6 期分類}

免疫賦活剂を投与した症例を検討する之，免疫賦活剤が臨床上からも 6 期分類上からす有効之思 われる症例を認めた。即ち, 経過のよい症例は 6 期分類上を時計回りに，経過の悪い症例は反時計 回りに動くことが示された. 6 期分類は個々の症例の経過を知るのによい方法であることが示され た。

\section{4 ) 末梢血リンパ球数}

癌根治治療法後のパラメーターとしては鋭敏に変化するとはいえない，しかし，長期間の経時的 推移を調べるととはある程度予後を知ることができ, 補助的なパラメーターとしては有用と考えら れた。

3. 免疫学的パラメータ一から見た免疫賦活剂の効果

免疫賦活剂の投与を行ない最低 1 年以上再発転移を認めない経過良好群に扣いて，免疫学的パラ メーターより免疫療法を評価した.

\section{1) $\mathrm{CH}_{50}$}

OK-432 使用群，PS-K 使用群，S SM使用群のいずれにおいても対照群に比べて $\mathrm{CH}_{50}$ が確 実に低下して抢り，半年すれば正常域に入って掞り，その有効性が推測された。

2) ツ反応

経過のよい症例のみのため，根治治療法後陰性のままの症例が少なく，陽転率や陽転までの期間 は検討できない。な捛，乙の群では根治治療法後の陰転例は認めていない.

3 ）末梢血リンパ球数

PS-K 使用群では投与前より正常域にあるためか変化が少ない．OK-432使用群，S S M 使用群 には末梢血リンパ球数の漸増が見られ, 特に O K-432 使用群に確実な增加傾向が認められた.

4. 結論

1）ＯK-432，PS-K， S S M はいわゆる担癌者に対して腫瘍縮小効果は認めなかった。

2）根治治療法後の再発転移防止に対してOK-432, PS-K, S SM は免疫学的検査よりある程 度の効果が推測された。

3 ）癌の免疫は解明されていない点も多く, 生体の免疫応答屯必ずしも有利に働くとは限らな 
い. 従って，免疫賦活剂の投与にも問題がある場合あ考えられる．乙の点につき今後の検討を待た ねばならない。

4）腫瘍縮小効果屯ふくめて，再発転移防止効果を一層高めるには，いわゆる免疫化学療法の検 討が必要である。

稿を終るに臨み，御指導と御校閲を賜った斎藤成司教授ならびに御助言を戴いた当大学微生物学教窒斎藤和 久教授沉深謝致します。 また終始直接㲹親身なる御指導と御教示を賜った犬山征夫講師沉謝意を表します。 さらに本研究行御妿力を戴いた当教室頭頸部腫㾮研究班の諸兄, また補体汇関して心温まる御教示之御便宜 を賜った東京都臨床医学総合研究所副所長西岡久寿弥博士, 都立大久保病院副院長河島敏夫博士, ならびに 当教室山崎嘉司講師㲹感謝致します。また，血清補体価測定に御援助下さった都立大久保病院研究室小町礼 子氏, 三須明美氏亿厚く御礼申上げます.

なお，本論文の要旨は第13回補体シンポジウム (昭和51年 9 月), 第14回日本癌治療学会総会 (昭和 51 年 9 月), 第 1 回頭頸腫煌学会 (昭和52年 7 月) にて発表した。本研究の一部は, 昭和51年度文部省科学研祝費補 助金にものである.

\section{文献}

1) Mathé, G. et al. : Active immunotherapy for acute lymphoblastic leukemia. Lancet I : 697 698, 1969.

2) Morton, D. L. et al. : Immunological factors which influence response to immunotherapy in malignant melanoma. Surgery $68:$ 158 164, 1970.

3 ) Morton, D. L. : Immunotherapy of cancer. Cancer $30: 1647 \sim 1655,1972$.

4) 山村雄一：癌の免疫療法の展望. 臨床免疫 6： 875 881, 1974.

5) Nishioka, K. et al. : The complement system in tumor immunity. Significance of elevated level of complement in tumor bearing host. Ann. New York Acard. Sci. 276 : 303 315, 1976.

6) 西岡久寿弥, 他: 補体の構造と機能に関する最近 の進歩. 代謝 $12: 189 \sim 193,1975$.

7 ) 河村一太, 他：補体の臨床. 臨床免疫 $7: 937$ $\sim 944,1975$.

8 ）漆崎一朗：腫愓抗原に対する体液性および細胞性 免疫. 臨床免疫 6：903 912，1974.

9 ）螺良英郎, 他：癌患者免疫能の診断パラメータ 一. 癌と化学療法 4:733 742, 1977.

10）中島康夫：頭頸部悪性腫煌患者の免疫能汇関する 臨床的研究一血清補体伍およびッベルクリン皮膚 反応を中心として-。耳鼻臨床 $70: 753 \sim 774$ ，
1977.

11) Busch, W. : Niederrheinische Gesellschaft für Natur-und Heilkunde in Bonn. Berlin. Klin. Wochenschrift $5: 137 \sim 138,1868$.

12) Okamoto, H. et al.: Studies on the anticancer and streptolysin S-forming abilities of hemolytic streptococci. Jap. J. Microbiol. II : 323 336, 1967.

13）木村揤郎, 他：溶連菌剤 $O K-432$ と癌の免疫化学 療法の可能性. 癌と化学療法 2:21３3, 1975

14）塚越茂：多糖類の担癌動物䎲対する宿主効果, 特 にカワラタケ由来, 蛋白糖, P S-K, の作用に ついて. 癌と化学療法 | : 251 257, 1974.

15）伊東一三：クレスチン. 癌と化学療法 4 ：425〜 430, 1977.

16）丸山千里：紹核菌体抽出物質（紹核ワクチン）に よる悪性腫沮の治療について。日医大誌 38 ： 267〜277, 1971.

17）三好朋子：結核ワクチン（丸山ワクチン）の生化 学的分析之その活性因子に関する研究。日医大誌 $36: 434 \sim 447,1969$.

18）中島康夫，他：頭頸部悪性腫瘍における免疫学的 検討. 耳鼻臨床 $69 ： 963 \sim 971,1976$.

19）犬山征夫，他：頭頸部悪性腫湯之血清補体洒. 日癌誌 $11 ： 711 \sim 719,1976$.

20）小川一誠，他：ピシバニールの抗腫煌作用に関し ての臨床的研究. 癌の臨床 $22: 735 \sim 739,1976$. 
21）田端敏秀, 他：覀性腫瘍の免疫学的アプローチ (第 6 報)。耳鼻臨床 $69: 1689 \sim 1696,1976$ 。

22）伊藤新一郎，他：末期癌に対する OK-432 の臨 床的検討. 癌と化学療法 4:839 847, 1977.

23）井沢道，他：小児白血病患者の免疫療法. 臨床免 疫 $6: 1015 \sim 1020,1974$.

24）吉崎和幸，他：メラノ一ム患者に対する免疫療 法. 臨床免疫 $6: 1021 \sim 1029,1974$.

25) Kondo, K. et al. : Activation of Cellular Immunity and Complement System in Immune-Deficient Aged Subjects by Streptococcal Preparation OK-432 (Picibanil). Jap.

J. Clin. Oncol. $7: 21 \sim 26,1977$.

26）藤田敬四郎，他：動物移植癌に対する「丸山口ク チン」（S SM）の効果. 基礎と臨床１/：37〜 44, 1977.

27）佐藤博：ラット腹水肝癌に対する人型結核菌体抽 出物質（丸山ワクチン・S S M ) の抗腫愓作用. 癌と化学療法 $5: 545 \sim 548,1978$.

28）河村一太，他：肺疾患と補体. 臨床免疫 3 ： 576 581， 1971.

29）楇武彦：人癌と免疫-癌と免疫応答. ライフサイ エンス社：4〜57, 1976 .

30) Sakamoto, M. et al. : Studies on Rat Complement 11. Complement Level in Experimental Tumor in Rats. Jap. J. Exp. Med. $45:$ 191 198, 1975.

31）岩森茂，他：癌患者における「ツベルクリン」反 応推移. 臨床先疫 I：705〜714, 1970 .

32）別役孝，他：胃癌病期別にみた各種抗原による皮 膚反応の検討. 癌と化学療法 $4: 753 \sim 759$, 1977.

33）伊東真人，他：頭頸部悪性腫䁑患者の遅延型皮膚 反応. 第 2 回頭頸部腫瘍学会予稿集：79, 1978.

34）折田薰三，他：担癌生体に打ける免疫不全. 臨床 免疫 $6: 549 \sim 556,1974$.
35）渡辺三作，他：癌患者とツベルクリン反応，神奈 川医学会誌 $3: 1 \sim 6,1975$.

36）稲井真弥，他：主として多糖による Alternative Pathway の活性化. 臨床免疫 $8: 281 \sim 287$, 1976.

37）西垣逸郎，他：溶連菌製剂 $\mathrm{OK}-432$ の免疫賦活作 用. 癌と化学療法 3:723〜 728, 1976.

38）木村郁郎，他：溶連菌剤に関する腫瘄免疫学的研 究 (第 1 報). 臨床免疫 7:1275 1278, 1975.

39）中野陽典，他：担癌マウスの遅延型皮膚反応にお よぼす蛋白多糖体（P S-K） の影響. 癌と化学 療法 I：285〜290，1974.

40）小谷野勝治：消化器癌症例に対する抗腫瘍蛋白多 糖体 P S-Kによる免疫化学療法. 癌の臨床 22 ： 777〜782, 1976.

41）田中冨子：人癌と免疫-B C G 生菌による癌の免 疫療法. ライフサイエンス社：238～253， 1976 .

42) Prehn, R. T. : The Immune Reaction as a Stimulator of Tumor Growth. Science 176 : 170 171, 1972 .

43) Prehn, R. T. : Immunological Surveillance. Immunobiol. 2 : 191 203, 1974.

44）星野孝, 他：癌の免疫刺激剤による免疫療法. 臨床免疫 $8: 1105 \sim 1114,1976$.

45）服部孝雄, 他：免疫療法の立場から. 医学のあゆ み $96: 402 \sim 409,1976$.

46）内田温土，他：OK-432皮内接種および F T-207 との併用による腫瘍の免疫化学療法. 癌と化学療 法 4 ：827〜832，1977.

47）中野陽典, 他：抗腫湯蛋白多糖体 P S-K 使用 した免疫化学療法. 癌と化学療法 2: 13～20, 1975.

原稿到着：昭和53年10月 2 日 別刷請求先：浅岡一之 干160 東京都新宿区信濃町35 慶応大学医学部耳鼻咽喉科学教室 